\title{
MAKNA INTELLECTUAL CAPITAL PERSPEKTIF THE ROLE THEORY DAN THE RESOURCE BASED THEORY
}

\author{
Sigit Hermawan \\ sigithermawan@umsida.ac.id \\ Fakultas Ekonomi, Universitas Muhammadiyah Sidoarjo
}

\begin{abstract}
This study is aimed to analyze the meaning of Intellectual Capital (IC) reviewed from the Role Theory and the Resources Based Theory. This is a qualitative study with interpretive paradigm. The data collection was conducted by in depth interview, Focus Group Discussion (FGD), and documentation. The data validity was tested using credibility, transferability, dependability, and confirmability test. The data analysis was conducted during the process of data collection, following some steps including data collection, data reduction, data display, and conclusion. The result of this study shows that IC plays a role in all operational activities of Pharmacy Company, improves innovation power, performance, competitiveness, and well-being. The party who plays a role in managing IC is the manager of Human Resource Development (HRD) for Human Capital (HC), the operational or production manager for Structural Capital (SC), and the marketing or sale manager for Relational Capital (RC). It is in accordance with the role theory. Meanwhile, this research is in line with the resource based theory because the company can obtain competitive advantage and superior performance by acquisition, and it can also obtain and use important strategic asset for competitive advantage and superior financial performance. The strategic assets are tangible asset and intangible asset including IC.
\end{abstract}

Keywords: Intellectual Capital, The Role Theory, The Resource Based Theory, Intangible Assets, Interpretive Qualitative.

\begin{abstract}
ABSTRAK
Tujuan penelitian ini adalah menganalisis makna Intellectual Capital (IC) ditinjau dari the role theory dan the resources based theory. Jenis penelitian adalah kualitatif dengan paradigma interpretive. Pengumpulan data dilakukan dengan in depth interview, Focus Group Discussion (FGD), dan pendokumentasian. Keabsahan data dilakukan dengan uji credibility, transferability, dependability, dan confirmability. Analisis data dilakukan selama proses pengumpulan data, dengan tahapan data collection, data reduction, data display, dan conclusion. Hasil penelitian menyatakan bahwa IC berperan bagi keseluruhan kegiatan operasional perusahaan farmasi, meningkatkan daya inovasi, kinerja, daya saing, dan kesejahteraan. Pihak yang berperan dalam mengelola IC adalah manajer Human Resource Development (HRD) untuk Human Capital (HC), manajer operasional atau produksi untuk Structural Capital (SC), dan manajer pemasaran atau penjualan untuk Relational Capital (RC). Hal ini sesuai dengan the role theory. Sementara itu, penelitian ini sesuai dengan the resource based theory karena perusahaan akan memperoleh competitive advantange dan kinerja superior melalui akuisisi, perolehan, dan penggunaan aset strategis yang penting untuk competitive advantage dan kinerja keuangan yang superior. Aset strategis yang dimaksud adalah aset berwujud dan aset tak berwujud termasuk IC.
\end{abstract}

Kata kunci: Intellectual Capital, The Role Theory, The Resource Based Theory, Aktiva Tak Berwujud, Kualitatif Interpretif.

\section{PENDAHULUAN}

Peran penting Intellectual Capital (IC) sebagai aktiva tak berwujud yang strategis bagi perusahaan telah terbukti melalui ber- bagai riset. Misalnya penelitian Hermawan (2011a, 2011b, dan 2011c), Hermawan dan Herlina (2013), Khalique et al. (2011), Sharabathi et al. (2010), Chen (2008), Cohen 
dan Kaimenakis (2007), Cabrita et al. (2007), Hsu (2006), Mageza (2004), Belkaoui (2003), IFAC (1998), dan Stewart (1997). Peran IC tersebut terbukti memengaruhi kinerja bisnis, meningkatkan nilai perusahaan, meningkatkan efektifitas organisasi, competitive advantage, dan juga menciptakan kesejahteraan bagi perusahaan.

Dengan memperhatikan peran IC yang demikian besar, seharusnya perusahaan farmasi di Indonesia dapat melakukan pengelolaan IC dengan baik. Namun, sampai saat ini pengelolaan IC oleh perusahan farmasi Indonesia masih sangatlah lemah. Terbukti hanya $17 \%$ perusahaan farmasi di Indonesia yang dapat bersaing di pasar ekspor khususnya Asia Tenggara (Sampoerno, 2007). Hal ini diperkuat oleh penelitian Hermawan, et al. (2012) yang menyatakan bahwa manajer perusahaan farmasi belum banyak mengetahui dan memahami komponen IC yang dimilikinya, belum mengetahui cara mengukur dan mengelolanya baik IC secara individual maupun IC secara integrasi. Padahal globalisasi industri dan harmonisasi farmasi ASEAN telah berjalan yang akhirnya menciptakan pasar tunggal farmasi di ASEAN. Hal ini memberikan peta persaingan industri farmasi yang lebih kompleks dan lebih berat. Kondisi ini harusnya memberikan kesadaran bagi perusahaan farmasi di Indonesia untuk menganalisis peran penting IC sehingga dengan mengetahuinya akan lebih memahami bagian atau komponen mana yang harus dikelola dan dikembangkan.

Dengan memperhatikan peran penting IC dan masih belum dikelolanya IC dengan baik oleh perusahaan farmasi, sangat perlu kiranya untuk melakukan riset dengan rumusan masalah bagaimana makna IC dalam perspektif the role theory dan the resource based theory di perusahaan farmasi. Makna yang dimaksud adalah makna peran IC. Dengan rumusan masalah yang demikian, tujuan penelitian ini adalah untuk menganalisis makna peran IC dalam tinjauan the role theory sehingga dapat dirumuskan pihak yang memainkan peran IC dan peran apa yang dimainkan oleh IC di perusahaan farmasi. Tujuan penelitian berikutnya adalah menganalisis makna peran IC dalam tinjauan the resource based theory sehingga dapat memberikan bukti yang lebih mendalam dan operasional bahwa IC mampu memengaruhi kinerja bisnis, meningkatkan daya saing, dan kesejahteraan bagi perusahaan.

\section{TINJAUAN TEORETIS}

Untuk memaknai peran penting IC digunakan the role theory (Linton, 1936; Elder, 1975) sebagai teori dasar. Teori ini akan menggambarkan peran IC dan "aktor" yang berperan dalam mengelola IC di perusahaan farmasi. Teori ini menggambarkan interaksi sosial dalam terminologi aktor-aktor yang bermain sesuai dengan apa yang ditetapkan oleh budaya. Sesuai dengan teori ini, harapan peran merupakan pemahaman bersama yang menuntun untuk berperilaku dalam kehidupan sehari-hari. Orang-orang yang mempunyai peran di bidang tertentu harus menunjukkan peran di bidangnya masingmasing.

Sementara itu, the resources based theory banyak digunakan sebagai referensi teori dari pengelolaan IC (Wernerfelt, 1984; Barney, 1991). Menurut the resource based theory (RBT) bahwa perusahaan akan memperoleh competitive advantange dan kinerja superior melalui akuisisi, memperoleh, dan menggunakan aset strategis yang penting untuk competitive advantage dan kinerja keuangan yang superior (Wernerfelt, 1984; Barney, 1991). Baik aktiva berwujud dan tak berwujud dirasakan sebagai aktiva strategis yang potensial. Menurut teori ini, bahwa manfaat dari kedua aktiva ini merupakan hasil yang positif antara sumber daya perusahaan dan pengukuran kinerja. Penyertaan aktiva tak berwujud diperoleh dari kemampuannya untuk memiliki seluruh karakteristik dari aktiva-aktiva strategis. Ketika kebanyakan aktiva tak berwujud tidak memiliki kualifikasi sebagai aktiva strategis, IC secara umum dipertimbangkan sebagai aktiva strategis yang penting. 
Dengan memiliki IC, berarti pengetahuan khusus dan berharga telah dimiliki oleh perusahaan. Kualifikasi IC sebagai aktiva strategis terletak pada hubungan yang sangat potensial antara IC dengan firm performance (Belkaoui, 2003).

IC sendiri diartikan secara berbeda dan beragam oleh banyak ahli. Berikut rangkuman definisi IC dari beberapa ahli:

Tabel 1

Definisi IC Menurut Para Ahli

\begin{tabular}{|c|c|}
\hline Ahli / Penulis & Definisi IC \\
\hline CIMA (2005) & $\begin{array}{l}\text { Perbedaan antara nilai pasar bisnis dengan aktiva berwujud (tangible } \\
\text { assets). }\end{array}$ \\
\hline $\begin{array}{l}\text { Choo dan } \\
\text { Bontis, (2002) }\end{array}$ & $\begin{array}{l}\text { Intellectual capital berisi modal yang berbeda yang berakar pada karya- } \\
\text { wan, rutinitas organisasi, hak kekayaan intelektual, dan hubungan } \\
\text { dengan pelanggan, suplier, distributor, dan rekan kerja. }\end{array}$ \\
\hline $\begin{array}{l}\text { Marr dan } \\
\text { Schiuma (2001) }\end{array}$ & $\begin{array}{l}\text { Kelompok aktiva pengetahuan yang dikaitkan dengan organisasi dan } \\
\text { secara signifikan berkontribusi terhadap posisi kompetitif organisasi } \\
\text { dengan menambahkan faktor-faktor kunci yang dimiliki stakeholders. }\end{array}$ \\
\hline Caddy (2000) & Perbedaan antara intangible assets dengan intangible liabilities. \\
\hline $\begin{array}{l}\text { Harrison dan } \\
\text { Sullivan (2000) }\end{array}$ & Pengetahuan yang dapat dikonversi ke dalam profit. \\
\hline Sveiby (1997) & $\begin{array}{l}\text { Berkaitan dengan pengalaman pengetahuan, kekuatan otak karyawan } \\
\text { seperti halnya sumber daya pengetahuan, yang disimpan di dalam } \\
\text { proses sistem database, budaya, dan filosofi. }\end{array}$ \\
\hline Brooking (1997) & $\begin{array}{l}\text { Intellectual capital secara operasional sebagai bahan intelektual yang } \\
\text { diformalkan, diperoleh, dan dikelola untuk menghasilkan aset yang } \\
\text { bernilai tinggi. }\end{array}$ \\
\hline Stewart (1997) & $\begin{array}{l}\text { Material intelektual-pengetahuan, informasi, hak intelektual, pengala- } \\
\text { man yang dapat digunakan untuk menciptakan kekayaan. }\end{array}$ \\
\hline Roos et al, (1997) & $\begin{array}{l}\text { Jumlah pengetahuan yang dimiliki oleh anggota perusahaan dan } \\
\text { terjemahan praktisnya seperti merk dagang, paten, dan brands. }\end{array}$ \\
\hline Bontis (1996) & $\begin{array}{l}\text { Intellectual capital sukar dipahami, tetapi sekali ditemukan dan } \\
\text { dieksplotasi, hal itu akan menyediakan pada organisasi sebuah sumber } \\
\text { daya baru untuk berkompetisi dan menang. }\end{array}$ \\
\hline
\end{tabular}

Sumber: Dirangkum dari Berbagai Referensi

Berdasarkan berbagai pengertian yang dikembangkan oleh para ahli dan penulis tersebut sebenarnya telah mengarah pada komponen yang ada di IC, yakni Human Capital (HC), Structural Capital (SC), dan Relational Capital (RC) (Marr, 2008; IFAC, 1998; Bontis et al, 2000; Edvinsson and Malone, 1997; Brooking, 1997). HC diartikan sebagai representasi dari stock pengetahuan individu yang tertanam di kapabilitas perusahaan secara kolektif untuk memberikan solusi-solusi terbaik dari para karyawan. Atau bisa juga dinyatakan sebagai segala kemampuan yang dimiliki oleh karyawan dalam menunjang tugasnya dan dalam mencapai tujuan perusahaan Bontis (1999 dan 2001). Sementara itu, SC diartikan sebagai segala sesuatu yang akan ditinggalkan di kantor ketika karyawan pulang (Bontis, 2001) atau pengetahuan yang berada di dalam perusahaan (CIMA, 2005). Selanjutnya, $R C$ diartikan sebagai seluruh sumber daya yang terkait dengan hubungan eksternal perusahaan beserta pelanggan, supplier, atau partner dalam riset dan pengembangan (CIMA, 2005). 
Adapun berbagai komponen $H C, S C$, dan $R C$ telah banyak dikembangkan oleh

para ahli. Berikut rangkumannya:

Tabel 2

Komponen $H C, S C$, dan $R C$

\begin{tabular}{|c|c|}
\hline IC & Komponen Kunci / Indikator \\
\hline $\begin{array}{l}\text { Human Capital } \\
\text { (HC) }\end{array}$ & $\begin{array}{l}\text { Kapasitas inovasi, kreativitas, "know how" atau tahu bagaimana, penga- } \\
\text { laman sebelumnya, kapasitas tim kerja, fleksibilitas karyawan, toleransi } \\
\text { atas perbedaan, motivasi, kepuasan karyawan, kapasitas pembelajaran, } \\
\text { loyalitas, pendidikan, pelatihan formal, kapabilitas, keberlanjutan karya- } \\
\text { wan, kualifikasi kejuruan, penilaian pekerjaan, penilaian psikometri, } \\
\text { inovatif, memiliki kemampuan proaktif dan reaktif, kemampuan untuk } \\
\text { berubah, pengetahuan dan ketrampilan, keterlibatan karyawan, kecer- } \\
\text { dasan emosional, jiwa kewirusahaan, fleksibilitas, kreativitas karyawan. }\end{array}$ \\
\hline $\begin{array}{l}\text { Structural } \\
\text { Capital (SC) }\end{array}$ & $\begin{array}{l}\text { Rutinitas organisasi, proses manajemen, prosedur, sistem, budaya, data- } \\
\text { base system, fleksibilitas organisasi, jasa dokumentasi, keberadaan pusat } \\
\text { pengetahuan, penggunaan umum teknologi informasi, kapasitas pem- } \\
\text { belajaran organisasi, budaya organisasi, hak intelektual, filosofi mana- } \\
\text { jemen, sistem informasi, sistem jaringan kerja. }\end{array}$ \\
\hline $\begin{array}{l}\text { Relational } \\
\text { Capital }(R C)\end{array}$ & $\begin{array}{l}\text { Loyalitas pelanggan, goodwill, relasi supplier, hubungan dengan masya- } \\
\text { rakat, image, kepuasan pelanggan, hubungan dengan supplier, hubungan } \\
\text { dengan pemegang saham, kekuatan komersil, kapasitas negosiasi } \\
\text { dengan entitas keuangan, aktivitas lingkungan, merek, nama perusa- } \\
\text { haan, channel distribusi, kolaborasi bisnis, perjanjian lisensi, kontrak- } \\
\text { kontrak yang menguntungkan, perjanjian waralaba, kapabilitas dasar } \\
\text { pemasaran, intensitas pasar. }\end{array}$ \\
\hline
\end{tabular}

Sumber: Dirangkum dari Berbagai Referensi

Sementara itu, IC banyak digunakan untuk keperluan pengukuran kinerja dan sampai tahun 2010 sudah terdapat 45 meto de pengukuran kinerja berbasis IC (Sveiby, 2010). Metode-metode tersebut kemudian dikelompokkan lagi ke dalam dua kelompok, yakni metode pengukuran keuangan dan pengukuran non keuangan. Namun menurut Hermawan (2010) bahwa pengukuran non keuangan mengungguli pengukuran keuangan pada IC karena kemanfaatan yang dirasakan oleh organisasi atau perusahaan di era ekonomi berbasis pengetahuan seperti saat ini.

\section{METODE PENELITIAN}

Penelitian ini dapat diklasifikasikan ke dalam penelitian kualitatif (Cresswell, 2007) dengan paradigma interpretive. Alasan memilih penelitian kualitatif interpretive karena penelitian ini banyak melakukan interpretasi atas pendapat informan dan mengungkap fenomena (Strauss dan Corbin, 2003) terkait makna IC dalam perspektif the role theory dan the resource based theory. Jenis penelitian kualitatif ini sangat tepat bila di kaitkan dengan pendapat Kong dan Ramia (2010) tentang alasan penggunaan metode kualitatif dalam penelitian IC. Alasannya adalah bahwa IC lebih banyak terkait dengan tacit knowledge atau pengetahuan tak tampak yang sering bersifat non verbal atau secara intuitif tidak dapat diverbalkan. Selain itu, IC juga sangat sulit untuk dikualifikasikan sehingga metode kualitatif dipilih untuk mengatasi masalah tersebut. Penelitian Nelson (2007) mendukung hal tersebut bahwa dibutuhkan metode kualitatif karena kebutuhan untuk menggali informasi, melakukan wawancara, dan mengidentifikasi 
dimensi yang sulit tentang aliran pengetahuan (baik yang eksplisit maupun implisit) yang merupakan bagian yang tidak terpisahkan dari IC.

Penelitian ini dilakukan di industri atau perusahaan farmasi karena termasuk kelompok industri highly intensive IC. Hal ini sesuai rekomendasi Sharabati et al. (2010) dan Chen et al. (2004) yang menyatakan bahwa penelitian IC lebih baik dilakukan di perusahaan manufaktur yang padat pengetahuan dengan tingkat penelitian yang tinggi dan inovatif dibandingkan dengan perusahaan lainnya. Salah satu perusahaan tersebut adalah perusahaan farmasi. Hal ini juga sejalan dengan rekomendasi Daum (2005), Boekestein (2006), Bramhandkar et al. (2007), dan Kamath (2008) yang menyatakan perusahaan farmasi adalah perusahaan yang memiliki seluruh karakteristik sebagai perusahaan berbasis pengetahuan karena banyak menggunakan riset. Selain itu, perusahaan farmasi juga banyak melakukan inovasi, banyak menggunakan pengetahuan, dan banyak melakukan interaksi antara manusia dan teknologi, serta bergantung pada IC sebagai sumber pembaruan.

Fokus penelitian adalah untuk menganalisis makna IC dalam perspektif the role theory dan the resource based theory. Makna IC yang dimaksud adalah makna peran IC bila dikaitkan dengan the role theory, yakni tentang bagaimana peran IC di perusahaan farmasi, siapa yang memerankan, dan seperti apa peran tersebut. Sementara itu, makna IC dalam perspektif the resource based theory berkaitan dengan IC sebagai intangible assets yang juga bermanfaat untuk meningkatkan kinerja superior dan competitive advantage perusahaan.

Unit analisis penelitian ini adalah pendapat informan tentang makna peran IC terkait siapa pihak yang memainkan peran, bagaimana peran IC dimainkan, dan seperti apa peran IC tersebut di perusahaan farmasi. Informan kunci dalam penelitian ini adalah manajer perusahaan farmasi (informan KK, ER, DS, AP), supervisor (informan NA), mantan manajer perusahaan farmasi (informan YAS), pengurus GP Farmasi Indonesia Jawa Timur (informan $\mathrm{M}$ dan AS), peneliti IC (informan WH dan ZF), dan pengamat industri farmasi (informan UA dan DH). Penentuan informan dilakukan dengan judgement dan snowball (Marshall, 1996).

Penelitian ini menggunakan in depth interview, focus group discussion (FGD), dan pendokumentasian untuk pengumpulan data (Marshall, 2006). In depth interview dilakukan dengan semua informan kunci baik di kantor maupun di luar kantor guna memudahkan wawancara. FGD dilakukan ber sama informan kunci yang telah dipilih (informan KK, ER, AP, DH, ZF). Pendokumentasian dilakukan dengan mengambil data yang relevan di Kantor Gabungan Perusahaan Farmasi Indonesia Cabang Jawa Timur (GPFI Jawa Timur), dan sejumlah literatur dari perpustakaan dan internet. Keabsahan data dilakukan dengan uji credibility, transferability, dependability, dan confirmability (Senton, 2004). Uji credibility (kredibilitas) dalam penelitian ini dilakukan dengan menggunakan empat triangulasi, yakni triangulasi metode, triangulasi sumber data, triangulasi teori, dan triangulasi antar peneliti (Hussien, 2009; Rahardjo, 2010). Uji transferability dilakukan dengan membuat laporan penelitian secara parsimoni, terinci, jelas, sistematis, dan dapat dipercaya karena dalam perspektif penelitian kualitatif, nilai transfer suatu penelitian tergantung pada pemakai, hingga mana hasil suatu penelitian dapat diterapkan pada situasi yang lain. Uji dependability dilakukan melalui pemeriksaan (audit) terhadap keseluruhan proses penelitian, yakni oleh pihak independen (Prof TS, Prof SS, Dr BP). Uji confirmability dilakukan dengan melibatkan beberapa orang yang pernah dan sedang menggeluti penelitian $I C$, yakni peneliti IU, SLWI, MBW, dan SH. Dengan melibatkan beberapa peneliti IC tersebut diharapkan hasil penelitian ini dapat lebih objektif sebagaimana tujuan uji confirmability. 
Proses analisis data dilakukan selama pengumpulan data. Proses seperti ini lazim digunakan dalam penelitian kualitatif sebagaimana rekomendasi Miles and Huberman (1984). Adapun tahapan analisis yang digunakan adalah data collection, data reduction, data display, dan conclusion. Pada tahapan data collection, semua data masuk apa adanya sesuai dengan hasil wawancara, $F G D$, dan dokumentasi. Namun dalam melakukan proses pengumpulan data, peneliti selalu mendasarkan pada panduan wawancara, panduan FGD dan panduan data dokumentasi yang dibutuhkan. Penyusunan panduan-panduan tersebut didasarkan pada rumusan masalah, tujuan dan fokus penelitian, teori pendukung, serta hasil riset terdahulu. Pada proses ini, peneliti juga berfungsi sebagai instrumen penelitian dengan menekankan pada keholistikan (holistic emphasis), mengembangkan dasar pengetahuan (knowledge based expansion), kesegeraan memproses (processual immediacy), dan kesempatan untuk mengklarifikasi dan meringkas (opportunity for clarification and summaryzation), serta dapat menyelidiki respon yang istimewa atau khas. Misalnya, pada saat melakukan wawancara, peneliti dapat melihat dan memahami mimik muka, gerak-gerik tubuh, dan ucapan informan tentang suatu hal termasuk penguasaan materi yang ditanyakan peneliti. Atas berbagai hal tersebut, peneliti dapat segera merespon dan beradaptasi dengan informan. Pada proses data collection juga dilakukan keabsahan data utamanya untuk uji kredibilitas (credibility) dengan cara triangulasi. Misalnya hasil wawancara satu informan di member check ke informan yang lain. Demikian juga dengan hasil wawancara dicross check dengan data dokumentasi, teori pendukung, atau juga dengan cara meminta tanggapan dari peneliti IC ataupun juga sebaliknya. Dengan cara yang demikian dapat lebih dijamin data yang diperoleh memiliki tingkat keabsahan yang tinggi.

Proses data reduction dilakukan selama penelitian berlangsung. Cara yang dilakukan dengan menyeleksi data yang terkait dengan tema atau topik penelitian yang telah ditentukan. Apabila data tidak terkait maka data direduksi atau dibuang. Data dengan tema atau konsep yang sama akan diberi kode (proses coding). Pada proses data reduction ini juga sangat dimungkinkan diketahuinya data yang diperoleh sudah cukup atau belum. Apabila belum cukup, peneliti kembali turun ke lapangan untuk mencari data sampai memenuhi aspek kecukupan data. Disinilah peneliti berperan kembali sebagai instrumen penelitian. Hasil dari data reduction akan dibuat data display dengan menyusun rangkaian wawancara ke dalam matriks display hasil penelitian. Berdasarkan matriks inilah peneliti dapat mengambil petikan-petikan wawancara yang penting untuk ditampilkan ke dalam pembahasan hasil penelitian dan juga untuk menunjukkan kealamiahan penelitian kualitatif. Tahap terakhir dari analisis data adalah conclusion. Pada tahap ini peneliti mengambil simpulan, pada awalnya sangat tentatif, tidak jelas, dan diragukan. Akan tetapi dengan bertambahnya data, simpulan akan lebih lengkap.

\section{ANALISIS DAN PEMBAHASAN}

Analisis data dilakukan dengan menggabungkan data-data yang diperoleh dari in depth interview, FGD, dan pendokumentasian. Dengan menggunakan empat triangulasi sebagai uji kredibilitas data dan data reduction dengan menggunakan coding, serta didukung oleh peneliti sebagai instrumen penelitian, peneliti mampu menghasilkan tema atau konsep yang sama atas makna peran IC. Berikut disajikan data konsep atau pola yang sama hasil dari proses analisis data. 
Tabel 3

Konsep atau Pola yang Sama Hasil dari Proses Coding

\begin{tabular}{ccc}
\hline \hline Coding & \multicolumn{2}{c}{ Tema atau Konsep } \\
\hline \multicolumn{1}{c}{ Tema atau Konsep Utama } \\
\hline A.1 & \multicolumn{2}{c}{ Peran Intellectual Capital di Perusahaan Farmasi } \\
A.2 & a. & Peran Penting Untuk Perusahaan Farmasi Secara Keseluruhan \\
A.3 & c. & Peran dan Kontribusi Untuk Menunjang Operasional dan Inovasi \\
& & Peran dan Kontribusi Untuk Meningkatkan Kinerja, Daya Saing \\
\hline
\end{tabular}

Sumber: Data Display Hasil Coding dan Data Reduction

Makna Peran Intellectual Capital Bagi Perusahaan Farmasi

Berdasarkan hasil penelitian yang menggali informasi, memahami, dan menganalisis pendapat para informan, dapat di ketahui tentang makna peran IC bagi perusahan farmasi. Berdasarkan proses coding dan data reduction, pendapat para informan tersebut dapat dikelompokkan menjadi tiga bagian, yakni 1) peran penting IC secara keseluruhan bagi perusahaan farmasi, 2) peran dan kontribusi IC untuk menunjang kegiatan operasional dan inovasi perusahaan, dan 3) peran dan kontribusi IC untuk meningkatkan kinerja, daya saing perusahaan farmasi, dan kesejahteraan (lihat tabel 3).

Untuk dapat sampai pada simpulan peran IC bagi perusahaan farmasi tersebut, peneliti tidak hanya mendasarkan pada analisis data dengan coding dan data reduction, tetapi juga dengan proses analisis selama pengumpulan data dan interpretasi dikaitkan dengan teori pendukung, yakni the role theory (Linton, 1936; Elder, 1975) dan resource based theory (Wernerfelt, 1984; Berney, 1991) (lihat tabel 3). Hal ini juga sebagai upaya melakukan uji credibility atau kredibilitas data khususnya pada triangulasi teori. Menurut the role theory, bahwa komponen-komponen tertentu diharapkan dapat memainkan peran dan berkontribusi nyata sesuai bidangnya masing-masing. Demikian pula dengan aktor yang memainkan peran tersebut. Apabila dikaitkan dengan peran $I C$, diharapkan ketiga komponen $I C$, yakni $H C, S C$, dan $R C$ dapat memainkan peran untuk pengelolaan SDM, struktural atau organisasi, dan juga hubungan atau relasi. Aktor yang memainkan peran tersebut juga harus memberikan kontribusi atas peran $H C, S C$, dan $R C$, yakni manajer $H R D$, manajer operasional dan produksi, manajer pemasaran dan penjualan (lihat tabel 4). Hasil penelitian yang lain tentang peran IC bagi peningkatan kinerja, daya saing, dan kesejahteraan. Hal tersebut sangat sesuai bila dikaitkan dengan resource based theory (Wernerfelt, 1984), yakni IC sebagai sumber daya yang dapat dikembangkan guna mendapatkan laba superior, meningkatkan kinerja, dan daya saing. Berikut dijelaskan hasil penelitian tentang makna peran IC di perusahaan farmasi.

\section{Peran Penting IC Bagi Perusahaan Farmasi Secara Keseluruhan}

Menurut para informan bahwa IC yang terdiri dari tiga komponen, yakni $H C, S C$, dan $R C$ sangat penting bagi perusahaan farmasi secara keseluruhan. Pertama, peran HC dan SC sangat besar karena produk obat yang dihasilkan perusahaan farmasi dari proses yang rumit, dan paling higienis dibanding dengan proses produksi industri lainnya (lihat tabel 4). Kedua, peran $R C$ pada pemasaran obat ethical (lihat tabel 4). Ketiga, peran IC untuk mengantisipasi penyakit dan keberlangsungan (sustainability) perusahaan (lihat tabel 4).

Peran penting IC tersebut ditunjukkan baik secara individual yakni $H C, S C, R C$, atau juga secara utuh sebagai IC (lihat tabel 4). Peran IC per komponan disesuaikan dengan aktivitas terkait $H C, S C$, dan $R C$ 
(lihat tabel 4). Peran IC sebagai satu kesatuan untuk internalisasi operasional perusahaan (lihat tabel 4). Menurut informan, komponen paling penting di perusahaan farmasi adalah HC karena sangat berperan mulai dari pemilihan bahan baku sampai menjadi obat siap jadi (lihat tabel 4). Para farmasis yang ada di perusahaan farmasi sudah dihadapkan pada banyaknya pilihan bahan baku yang akan digunakan dalam pembuatan obat. Pada aspek ini, sering kali terjadi dilema bagi para farmasis untuk memilih bahan baku berkualitas, tetapi harganya mahal atau bahan baku kualitas rendah, tetapi harganya murah. Idealisme seorang farmasis dihadapkan pada realitas perhitungan aspek ekonomi. Pada aspek ini saja, peran seorang farmasis $(H C)$ di perusahaan farmasi sudah begitu besar terhadap kualitas obat yang akan dihasilkan. Pada proses berikutnya, setelah bahan baku dipilih dan proses produksi berjalan, peran farmasis (HC) juga sangat besar karena bertugas menjaga mutu obat. Semua proses harus diawasi dengan sangat ketat. Berbagai aturan yang rumit harus dijalankan sebagaimana Cara Pembuatan Obat Yang Baik (CPOB) sebagai sistem operasional prosedur (SOP) proses produksi bagi perusahaan farmasi. Pada saat obat sudah jadi, peran farmasis juga sangat besar karena tidak semua obat bagus kualitasnya, bahkan harus ada pula yang di-reject. Aspek etika dan moral juga menjadi hal penting bagi seorang farmasis dalam menjalankan tugasnya. Proses produksi obat di industri farmasi juga paling higienis dibanding dengan proses produksi pada industri lainnya, mulai dari penyimpangan bahan baku sebelum produksi sampai menjadi produk jadi (lihat tabel 3). Misalnya, kelembaban udara yang ada di gudang juga harus diatur sedemikian rupa, interaksi manusia dengan senyawa kimia aktif juga menjadi perhatian khusus, inilah bukti bahwa peran $H C$ dan $S C$ dalam industri farmasi sangatlah besar. Begitu besarnya peran HC sudah selayaknya HC dalam bentuk human resource menjadi aset penting bagi perusahaan farmasi (lihat tabel 4).

Peran pentingnya IC bagi perusahaan farmasi juga terkait dengan produk yang dihasilkan adalah bahan yang masuk ketubuh manusia dengan tujuan untuk menyembuhkan penyakit, bukan untuk membuat sakit. Dengan demikian, proses produksi yang dilakukan harus dengan sangat hati-hati mulai dari penerimaan bahan baku sampai menjadi obat jadi. Bahkan tidak hanya mengatur proses produksi melalui Cara Pembuatan Obat Yang Baik (CPOB) saja, tetapi juga proses distribusinya diatur melalui Cara Distribusi Obat Yang Baik (CDOB). Pada aspek ini, peran HC dan SC lebih banyak berperan bagi perusahaan farmasi. Untuk memastikan bahwa produk farmasi adalah produk paling higienis dan paling rumit proses produksinya, peneliti melakukan triangulasi metode dengan membandingkan antara hasil wawancara dari informan YAS dengan data dokumentasi, yakni tentang Cara Pembuatan Obat yang Baik (BPOM RI, 2006) (lihat tabel 4). Hasilnya memang produk farmasi dihasilkan dari proses yang rumit, bertahap, dan paling higienis dibanding dengan produk yang lain.

Peran lain juga ditunjukkan oleh $R C$ karena obat yang ada di industri farmasi ini dapat digolongan menjadi dua obat, yakni obat OTC (Over the Counter) dan ethical. Pemasaran obat ethical inilah yang membedakan dengan pemasaran industri lainnya. Prinsip-prinsip etis harus menjadi pijakan dalam melakukan pemasaran obat ethical ini. Ada kode etik pemasaran farmasi Indonesia yang harus menjadi pedoman dan pijakan dalam melakukan aktivitas promosi, misalnya larangan menyebutkan bahwa obat itu "terbaik, tercepat, terkuat/ termanjur, teraman". Hal inilah yang membedakan dengan pemasaran pada produk industri lainnya. Dengan demikian, peran $R C$ pada industri farmasi yakni terkait dengan dua model pemasaran obat yang harus dilakukan secara langsung untuk obat OTC, dan tidak langsung untuk obat ethical 
(lihat tabel 4). Untuk dapat memastikan tentang kode etik pemasaran, peneliti melakukan triangulasi metode dengan membandingkan hasil wawancara dengan data dokumentasi tentang kode etik pemasaran (ISFI, 2009). Hasilnya memang ada kaidahkaidah dan aturan tentang cara melakukan promosi bagi obat atau produk farmasi.

Peran IC bagi perusahaan farmasi secara keseluruhan juga terkait dengan perkembangan penyakit yang harus diantisipasi, dan juga untuk keberlangsungan hidup (sustainability) perusahaan (lihat tabel 4). Antisipasi perkembangan penyakit perlu dilakukan oleh perusahaan farmasi. Antisipasi penyakit ini tidak hanya penyakit yang berkembang, tetapi juga proteksi atas berbagai penyakit yang akan menyerang tubuh. Hal inilah yang sekarang banyak dilakukan oleh perusahaan farmasi dengan memproduksi bahan makanan atau minuman kesehatan atau health care. Di sinilah peran IC untuk dapat melakukannya. Dengan mengombinasikan $H C, S C$, dan $R C$, upaya tersebut dapat dilakukan. Berbagai peluang yang ada di masyarakat ditangkap oleh $R C$, kemudian diproses oleh $H C$ dan $S C$ menjadi obat atau produk kesehatan baru yang nantinya akan menjadi produk andalan bagi perusahaan farmasi. Apabila hal tersebut dapat dilakukan, keberlangsungan (sustainability) perusahaan farmasi akan dapat terjaga.

Dengan demikian, apabila dikaitkan dengan hasil penelitian sebelumnya, bahwa penelitian ini sesuai dengan hasil penelitian Khalique et al. (2011), yang menjelaskan bahwa peran IC adalah sebagai aset strategis utama bagi organisasi di dalam ekonomi berbasis pengetahuan seperti saat ini (lihat tabel 4). Penelitian ini juga sesuai dan mampu menjelaskan hasil penelitian Sharabati et al. (2010), yang dilakukan di perusahaan farmasi di Jordania (lihat tabel 4). Hasil penelitian tersebut menyatakan bahwa untuk mendapatkan hasil maksimal dari konsep IC, perusahaan farmasi harus memberi perhatian lebih pada IC baik secara individual $H C, S C, R C$ atau juga IC secara utuh (lihat tabel 4). Artinya, memang perusahaan farmasi harus dapat memainkan peran IC untuk tiap-tiap individu karyawan, kelompok karyawan, atau yang ada di tiap-tiap departemen, dan seluruh perusahaan.

Tabel 4

Hasil Penelitian dan Uji Credibility (Triangulasi Metode dan Triangulasi Teori-Riset Pendukung)

\begin{tabular}{|c|c|c|}
\hline Makna Peran IC & Operasionalisasi Peran & Uji Credibility \\
\hline $\begin{array}{l}\text { Aktor atau pihak } \\
\text { yang memainkan } \\
\text { peran IC }\end{array}$ & $\begin{array}{l}\text { - Manajer SDM atau human resource } \\
\text { development (HRD) untuk penge- lolaan } \\
\text { HC } \\
\text { - Manajer operasional dan produksi untuk } \\
\text { pengelolaan SC } \\
\text { - Manajer pemasaran dan penjualan untuk } \\
\text { pengelolaan } R C \\
\text { - Komponen paling penting dan berperan } \\
\text { adalah HC serta merupa- kan aset bagi } \\
\text { perusahaan farmasi }\end{array}$ & $\begin{array}{l}\text { - The role theory } \\
\text { (Linton, 1936; Elder, } \\
\text { 1975). } \\
\text { - The Resource based } \\
\text { theory (Wernerfelt, } \\
\text { 1984; Berney, 1991) }\end{array}$ \\
\hline $\begin{array}{l}\text { Cara memainkan } \\
\text { peran } I C\end{array}$ & $\begin{array}{l}\text { - IC dapat berperan per komponen }(H C \text {, } \\
S C, R C) \text { atau juga } I C \text { sebagai kesatuan } \\
\text { yang utuh. } \\
\text { - Peran } I C \text { per komponen disesuai- kan } \\
\text { dengan aktivitas terkait } H C, S C \text {, dan } R C \text {. }\end{array}$ & \\
\hline
\end{tabular}


- Peran IC sebagai satu kesatuan untuk internalisasi operasional perusahaan.

- IC sebagai satu kesatuan berperan untuk peningkatan kinerja, daya saing, dan kesejahteraan

Peran Penting IC - Peran HC dan SC untuk produksi obat Bagi Perusahaan Farmasi Secara Keseluruhan dari proses yang rumit dan paling higienis dibanding proses produksi industri lainnya.

- Peran RC pada pemasaran obat ethical.

- Peran IC untuk mengantisipasi penyakit dan keberlangsungan (sustainability) perusahaan.

- Cross check antara in
depth interview YAS
dan UA dengan
dokumentasi (CPOB,
CDOB, kode etik
pemasaran farmasi)
- Khalique et al. (2011)
- Sharabati et al. (2010)
depth interview YAS dan UA dengan dokumentasi (CPOB, CDOB, kode etik - Khalique et al. (2011) - Sharabati et al. (2010)

Sumber: Data Display dan Data Reduction

Peran Penting dan Kontribusi IC untuk Menunjang Kegiatan Operasional dan Inovasi Perusahaan

Menurut para informan bahwa IC sangat berperan dan berkontribusi untuk menunjang kegiatan operasional dan inovasi perusahaan. Kegiatan operasional yang di maksud adalah aktivitas harian yang ada di perusahaan farmasi. IC sebagai satu kesatuan saling mendukung hal tersebut. $H C$ akan mendukung aktivitas $S C$ dan $R C$, dan demikian pula sebaliknya (lihat tabel 4). Hal tersebut dinyatakan informan $\mathrm{KK}$, bahwa IC berperan untuk menunjang operasional perusahaan. Antara HC dalam bentuk human resource dengan $R C$ dalam bentuk marketing, dan SC dalam bentuk produksi saling terkait dan berhubungan erat. Berikut pernyataan informan KK:

"Tentunya tetap berhubungan erat karena keberlangsungan human resource (human capital) sendiri tergantung dari bagian marketing. Karena marketing yang menyiapkan jumlah produksi yang harus disiapkan berapa, dia yang jual produk, dia yang tentukan produk apa yang harus di develop, mengembangkan produk apa, kapasitasnya bagaimana? Pasti ada keterkaitan, tidak bisa terpisah" (Petikan wawancara dengan KK, 08-03-2012).

Keterkaitan atau interkoneksi antara marketing dan produksi juga dinyatakan oleh informan $\mathrm{M}$, bahwa pada setiap tahunnya bagian marketing membuat forecast yang kemudian akan dibuat perhitungannya oleh PPIC, dan akan dikerjakan produksinya oleh departemen produksi (lihat tabel 5). Informan ER sebagai manajer PPIC membenarkan tentang interkoneksi antara marketing, produksi, dan PPIC. Demikian juga dengan informan DS sebagai manajer produksi juga memberikan pendapat yang sama. Kegiatan produksi tidak akan bisa berjalan dengan baik bila tidak didukung sistem prosedur, teknologi informasi, mesin mesin, peralatan $(S C)$, dan yang terpenting adalah support ketersediaan sumber daya manusia (HC). Berdasarkan hasil in depth interview dengan informan $\mathrm{KK}, \mathrm{M}$, ER, dan DS berikutnya peneliti melakukan member check kepada informan AP yang menyatakan hal yang sama, yakni $H C$ menyediakan farmasis yang dapat memenuhi ketentuan Cara Pembuatan Obat yang Baik (CPOB) dan sistem prosedur lainnya (SC) serta juga medical representative yang mampu melakukan aktivitas $R C$ baik strategic maupun operasional (lihat tabel 5). Artinya, memang peran IC dalam menunjang kegiatan operasional perusahaan farmasi diwujudkan dalam bentuk interkoneksi antar departemen (lihat tabel 5).

Peran dan kontribusi IC tidak hanya untuk kegiatan operasional perusahaan, 
tetapi juga untuk inovasi dan pengembangan produk dengan cara selalu mengembangkan ketiga komponen IC tersebut (lihat tabel 5). Hal tersebut dimaksudkan agar perusahaan farmasi dapat selalu mengantisipasi dan memenuhi keinginan pasar. Inovasi dan pengembangan produk dapat dilakukan oleh $R C, H C$ ataupun juga $S C$. Artinya, IC memang dapat dijadikan sebagai sumber inovasi bagi perusahaan farmasi. $R C$ menangkap peluang inovasi dari para pelanggan atau customer, $\mathrm{HC}$ memberikan ide inovasi dari para karyawan perusahaan, dan SC memberikan ide inovasi dari tuntutan $S O P$ yang mengharuskan perusahaan farmasi berubah melakukan perbaikan dan inovasi (lihat tabel 5).

Dengan demikian, apabila dikaitkan dengan hasil penelitian sebelumnya, bahwa penelitian ini mendukung dan mampu menjelaskan salah satu hasil penelitian Hsu (2006), yakni HC berpengaruh secara tidak langsung terhadap efektivitas organisasi melalui SC. Artinya, bahwa HC (farmasis atau apoteker) dapat menjalankan $\mathrm{CPOB}$ yang merupakan SOP proses produksi obat sehingga kegiatan operasional perusahaan dapat berjalan dengan lancar dan mutu obat terjamin. Namun, hasil penelitian ini berbeda dengan salah satu hasil penelitian Ghosh dan Mondal (2009), yang menyatakan bahwa IC tidak berpengaruh pada produktivitas perusahaan farmasi dan software di India. Artinya, IC tidak berperan dan tidak berkontribusi pada produktivitas.

Penelitian ini juga dapat digunakan untuk menjelaskan hasil penelitian Shih et al. (2010), yakni bahwa HC berpengaruh positif terhadap SC. Artinya, dalam penelitian ini $H C$ sangat penting dan berkontribusi pada kegiatan $S C$ dengan menyediakan SDM berkualitas, yakni farmasis atau apoteker yang diberdayakan oleh perusahaan farmasi untuk melakukan riset, memproduksi, dan menjaga mutu obat dengan melaksanakan apa yang ada di CPOB. Peran lain $H C$ untuk $S C$ adalah membuat sistem prosedur, tata aturan kerja, menciptakan budaya profesional dan inovatif yang membuat HC mampu membuat layanan dan produk-produk baru bagi perusahaan farmasi. Tentang berperannya HC untuk kegiatan SC ini didukung pula oleh penelitian Cabrita dan Bontis (2008), Hsu (2006), Moon dan Kym (2006), Chen et al. (2004), dan Bontis et al. (2000) (lihat tabel 5).

Contoh lain tentang peran $H C$ bagi kegiatan $R C$ adalah dengan menyediakan medical representative (med rep) yang secara khusus digunakan untuk memasarkan produk obat ethical kepada dokter dan tenaga kesehatan lainnya. Peran lain HC tentunya terkait penyediaan tenaga-tenaga marketing, untuk mempromosikan, pencitraan, dan kegiatan-kegiatan CSR yang mampu memperkenalkan produk-produk farmasi. Peran $H C$ ini juga secara berkesinambungan dapat menciptakan brand image dan brand product bagi perusahaan farmasi. Hasil penelitian ini memang sesuai dengan penelitian Chen et al. (2004), Bontis et al. (2000), Shih et al. (2010), Cabrita dan Bontis (2008), Moon dan Kym (2006) (lihat tabel 5). Hasil-hasil penelitian tersebut menyatakan bahwa HC berpengaruh terhadap $R C$.

Penelitian ini juga mendukung dan mampu menjelaskan hasil penelitian lain, seperti penelitian Cabrita dan Bontis (2008), Cabrita et al. (2007), Bontis dan Fitz-Enz (2002), yakni SC berpengaruh terhadap $R C$. Artinya, bahwa sistem prosedur, mekanisme kerja, struktur organisasi, proses organisasi, dan budaya organisasi yang ada di perusahaan farmasi mampu berperan dan mendukung kegiatan $R C$, seperti promosi ke dokter, pelayanan pada pasien, kepuasan pengguna obat, layanan kepada tenaga kesehatan, dan kegiatan CSR perusahaan farmasi. Pada tataran operasional, memang perusahaan farmasi telah menyusun strategi dengan membuat dua struktur penting yakni bagian marketing strategic dan bagian marketing operational. Dua bagian ini menjadi ujung tombak keberhasilan $R C$ yang dilakukan oleh perusahaan farmasi. 
Tabel 5

Hasil Penelitian dan Uji Kredibilitas (Triangulasi Sumber dan Riset Pendukung)

\begin{tabular}{|c|c|c|}
\hline Peran IC & Operasionalisasi & Uji Credibility \\
\hline $\begin{array}{l}\text { Peran Penting dan } \\
\text { Kontribusi IC Untuk } \\
\text { Menunjang Kegiatan } \\
\text { Operasional }\end{array}$ & $\begin{array}{l}\text { - Interkoneksi antara } H C, S C \text {, dan } R C \text {. } \\
\text { - } H C \text { akan mendukung aktivitas } S C \text { dan } \\
R C \text {, dan demikian pula sebaliknya } \\
\text { - } H C \text { menyediakan farmasis yang dapat } \\
\text { memenuhi ketentuan } C P O B(S C) \text { dan } \\
\text { juga medical representative yang mampu } \\
\text { melakukan aktivitas } R C \text { baik strategic } \\
\text { maupun operasional. }\end{array}$ & $\begin{array}{l}\text { - Member check infor- } \\
\text { man M, KK, ER, } \\
\text { AP, dan DS } \\
\text { - Cabrita dan Bontis } \\
\text { (2008) } \\
\text { - Cabrita et al. (2007) } \\
\text { - Bontis dan Fitz-Enz } \\
\text { (2002) }\end{array}$ \\
\hline $\begin{array}{l}\text { Peran dan kontribusi } \\
\text { IC untuk inovasi } \\
\text { perusahaan }\end{array}$ & $\begin{array}{l}\text { - IC dapat menjadi sebagai sumber ino- } \\
\text { vasi bagi perusahaan farmasi. } \\
\text { - } R C \text { menangkap peluang inovasi dari } \\
\text { para pelanggan atau pasar, HC mem- } \\
\text { berikan ide inovasi dari para karya- } \\
\text { wan perusahaan, dan } S C \text { memberikan } \\
\text { ide inovasi dari tuntutan CPOB yang } \\
\text { mengharuskan perusahaan farmasi } \\
\text { selalu melakukan perbaikan dan } \\
\text { inovasi. }\end{array}$ & $\begin{aligned} & \text { - } \text { Cabrita dan Bontis } \\
&(2008) \\
& \text { - } \text { Hsu (2006) } \\
& \text { - } \text { Moon dan Kym } \\
&(2006) \\
& \text { - Chen et al. }(2004) \\
& \text { - Bontis et al. (2000) }\end{aligned}$ \\
\hline
\end{tabular}

Sumber: Data Display dan Data Reduction

Peran Penting dan Kontribusi IC untuk Meningkatkan Kinerja, Daya Saing Perusahaan Farmasi, dan Kesejahteraan

Menurut pendapat informan bahwa IC sangat berperan dan berkontribusi pada peningkatan kinerja, daya saing perusahaan farmasi, dan kesejahteraan. Untuk dapat sampai pada kinerja, daya saing, dan kesejahteraan, haruslah diawali dari karyawan (HC) yang kreatif dan inovatif, termasuk yang ada di bagian marketing. HC yang ada di bagian marketing harus terus meningkatkan knowledge yang dimilikinya agar dapat melayani customer, dan juga dapat memenuhi keinginan konsumen. Berbagai bentuk keluhan dari pelanggan akan disampaikan ke manajemen perusahaan. Berikutnya, perusahaan menyiapkan SDM untuk melakukan inovasi sehingga dapat memenuhi keinginan market. Apabila sudah demikian, perusahaan akan dapat meningkatkan sales yang berarti kinerja meningkat dan daya saing semakin menguat. Akhirnya, kesejahteraan perusahaan dan pemilik akan juga meningkat.
Peran IC untuk meningkatkan kinerja, daya saing, dan kesejahteraan disampaikan oleh informan $\mathrm{WH}$, yakni:

"Jadi IC itu penting dan berperan untuk ke operasional, kinerja, dan daya saing. Yang namanya IC itu terbentuknya memang digunakan untuk memperkuat operasional dulu pak Sigit. Jadi kalau operasional itu sudah kuat baru nanti dapat digunakan untuk meningkatkan kinerja atau juga untuk meningkatkan daya saing. Dan pada akhirnya akan meningkatkan kesejahteraan semua komponen perusahaan termasuk karyawan" (Petikan wawancara dengan WH, 20-042012).

Berdasarkan pernyataan informan $\mathrm{WH}$ tersebut dapat dijelaskan tentang bagaimana peran IC bagi perusahaan farmasi, yakni pertama untuk kegiatan operasional, kemudian untuk inovasi. Apabila kegiatan operasional dan inovasi sudah dapat dilakukan oleh perusahaan farmasi, IC akan dapat digunakan untuk meningkatkan ki- 
nerja, daya saing, dan akhirnya dapat meningkatkan kesejahteraan perusahaan dan karyawan (lihat tabel 6). Pendapat yang tidak jauh berbeda disampaikan oleh informan ZF sebagai peneliti IC. Pernyataan informan $\mathrm{WH}$ tersebut sekaligus sebagai upaya yang dilakukan oleh peneliti dalam melakukan uji credibility khususnya pada triangulasi antar peneliti (lihat tabel 6).

Menurut para informan, perusahaan farmasi akan lebih mudah mencapai kinerja, daya saing, dan kesejahteraan apabila telah memiliki produk branded, produk paten atau produk leader, dan juga brand image yang dimiliki perusahaan (lihat tabel 6). Produk-produk ini memang memudahkan dalam hal promosi dan juga meyakinkan dokter (untuk produk ethical), apalagi kalau dari perusahaan farmasi besar, para dokter akan lebih apresiatif. Dengan mudahnya untuk melakukan promosi dan lebih meyakinkan pembeli pertama, yakni dokter maka kinerja dan daya saing (competitive advantage) perusahaan akan lebih mudah untuk diraih. Pada akhirnya kesejahteraan perusahaan, pemilik perusahaan, dan karyawan akan meningkat. Terkait produk branded ini, informan DH menjelaskan hal tersebut.
"Itu biasanya disebut dengan produk yang orisinal ya. Produk-produk itu biasanya disebut dengan produk leader di market itu ya pak. Dan itu memang lebih enak ya dalam promosi apalagi kalau perusahaan besar kan lebih meyakinkan. Dokterpun biasa- nya lebih apresiatif kalau perusahaan besar" (Petikan wawancara dengan DH, 14-04-2012).

Dengan memiliki produk leader atau brand product tentunya akan memengaruhi kinerja khususnya kinerja keuangan. Hal tersebut dinyatakan juga oleh informan NA (lihat tabel 6). Pendapat informan $\mathrm{DH}$ dan NA dijadikan bahan untuk kegiatan FGD, hasilnya juga menyatakan hal yang sama bahwa perusahaan farmasi harus memiliki leader product dengan cara berinovasi sendiri untuk produk-produk health care melalui departemen research and development (RND) atau memanfaatkan produk paten yang sudah off paten. Hal ini merupakan cara perusahaan farmasi memiliki keunggulan untuk produknya.

Apabila dicermati pernyataan para informan baik hasil dari in depth interview ataupun FGD bahwa peran dan kontribusi IC terhadap kinerja, daya saing, dan kesejahteraan dapat tercapai apabila perusahaan farmasi telah memiliki brand image atau branded product yang sudah dikenal luas oleh masyarakat. Baik brand image perusahaan dan brand product farmasi, keduanya akan sangat membantu untuk mengangkat kinerja perusahaan. Apabila perusahaan telah memiliki brand product berupa obat yang mudah dan selalu diingat oleh masyarakat, hal ini memudahkan penjualan obat yang bersangkutan. Dampaknya dapat dipastikan bahwa sales perusahaan farmasi yang bersangkutan akan selalu meningkat. Demikian juga sebaliknya, apabila perusahaan farmasi sudah memiliki brand image bagus sebagai perusahaan farmasi terpercaya, hal ini akan dapat mengangkat produk obat yang sebenarnya kualitasnya biasa-biasa saja.

Dengan demikian, apabila dikaitkan dengan hasil penelitian sebelumnya bahwa penelitian ini mendukung dan mampu menjelaskan hasil penelitian lain, seperti hasil penelitian Sharabati et al. (2010), Ghosh dan Mondal (2009), Bramhandkar et al. (2007), Chen et al. (2004), Cabrita dan Bontis (2007), Bontis et al. (2000), Chen (2008), Stewart (1997), dan Mageza (2004) (lihat tabel 5). Artinya, bahwa farmasis yang berkualitas, unggul, mampu menjaga mutu obat, dan mampu melaksanakan CPOB dengan baik, dapat dipastikan akan menghasilkan mutu obat yang diminati oleh konsumen (lihat tabel 6). Apalagi bila hal tersebut ditunjang oleh strategi marketing, tim sales yang bagus, dan kerja sama yang baik dengan berbagai pihak, tentunya hal ini secara bertahap akan menjadikan produk farmasi menjadi obat branded dan 
menjadikan perusahaan farmasi dikenal, serta mendapat brand image yang bagus (lihat tabel 6). Dengan memiliki obat branded dan brand image yang bagus untuk perusahaan farmasi, maka dapat dipastikan hal ini akan mampu meningkatkan kinerja, daya saing perusahaan farmasi, dan pada akhirnya akan menciptakan kesejahteraan bagi perusahaan dan pemilik (pemegang saham) perusahaan.

Ketiga peran dan kontribusi IC di perusahaan farmasi tersebut memang sesuai dengan the role theory (Elder, 1975) dan the resource based view of the firm (Wernerfelt, 1984; Berney, 1991) (lihat tabel 6). Kedua teori tersebut memang sangat sesuai bila dikaitkan dengan peran dan kontribusi tiap komponen IC bagi perusahaan farmasi, dan juga kemampuan sumber daya tak berwujud IC dalam memberikan kontribusi pada kinerja dan daya saing perusahaan.

Kesesuaian hasil penelitian ini dengan the role theory (Elder, 1975), nampak pada peran dan kontribusi komponen $H C, S C$, dan $R C$ baik secara individual tiap komponen maupun secara utuh sebagai $I C$, demikian pula dengan aktor yang melaksanakan peran tersebut. HC berperan dalam penyediaan dan pengelolaan SDM. SC berperan dalam menyediakan perangkat organisasi dan teknologi dalam operasional perusahaan. $R C$ berperan dalam berbagai bentuk kerja sama, relasi, dan promosi. Peran-peran inilah yang mendukung proses IC dapat berkontribusi pada operasional, inovasi, kinerja, daya saing, dan kesejahteraan. Apabila dikaitkan dengan aktor yang berperan, minimum ada tiga manajer yang paling berperan dan berkontribusi atas pengelolaan IC di perusahaan farmasi, yakni manajer SDM $(H C)$, manajer produksi $(S C)$, dan manajer pemasaran (RC). Peran ketiga manajer tersebut memang sesuai dengan penelitian Sofian et al. (2005).

Kesesuaian hasil penelitian ini dengan the resource based theory (Wernerfelt, 1984; Berney, 1991) karena hasil penelitian ini menyatakan bahwa IC berperan dan memiliki kontribusi pada kinerja, daya saing, dan kesejahteraan. Dalam penelitian ini, HC dalam bentuk SDM (farmasis dan med rep), yang ditunjang oleh SC dalam bentuk sistem prosedur kerja, pelaksanaan $\mathrm{CPOB}$, dan budaya kerja inovatif, serta $R C$ dalam bentuk marketing strategic, marketing operational, dan tim sales yang tangguh memainkan peran untuk menunjang kegiatan operasional, inovasi, meningkatkan kinerja bisnis, daya saing perusahaan, dan kesejahteraan. Artinya, dengan mengelola IC yang baik, perusahaan farmasi akan memperoleh kinerja superior dan competitive advantange. Hal ini disebabkan, ketika kebanyakan aktiva tak berwujud tidak memiliki kualifikasi sebagai aktiva strategis, IC secara umum dipertimbangkan sebagai aktiva strategis. Kualifikasi IC sebagai aktiva strategis terletak pada hubungan yang sangat potensial antara IC dengan firm performance (Belkaoui, 2003).

\section{Tabel 6 \\ Hasil Penelitian dan Uji Credibility (Triangulasi Antar Peneliti dan Triangulasi Teori-Riset Pendukung)}

\begin{tabular}{|c|c|c|}
\hline Peran IC & Operasionalisasi & Uji Credibility \\
\hline $\begin{array}{l}\text { Peran Penting dan } \\
\text { Kontribusi IC Untuk } \\
\text { Meningkatkan } \\
\text { Kinerja, Daya Saing } \\
\text { Perusahaan Farmasi, } \\
\text { dan Kesejahteraan }\end{array}$ & $\begin{array}{l}\text { IC untuk kegiatan operasional, } \\
\text { kemudian untuk inovasi, daya } \\
\text { saing, kinerja, dan kesejahteraan. } \\
\text { Farmasis yang berkualitas, } \\
\text { unggul, mampu menjaga mutu } \\
\text { obat, dan mampu melaksanakan } \\
\text { CPOB dengan baik, dapat di- }\end{array}$ & $\begin{array}{l}\text { - Informan WH, ZF, NA, } \\
\text { dan DH } \\
\text { - The role theory (Elder, } \\
\text { 1975) } \\
\text { - The resource based view } \\
\text { of the firm (Wernerfelt, } \\
\text { 1984; Berney, 1991) }\end{array}$ \\
\hline & pastikan akan & - Hermawan \\
\hline
\end{tabular}




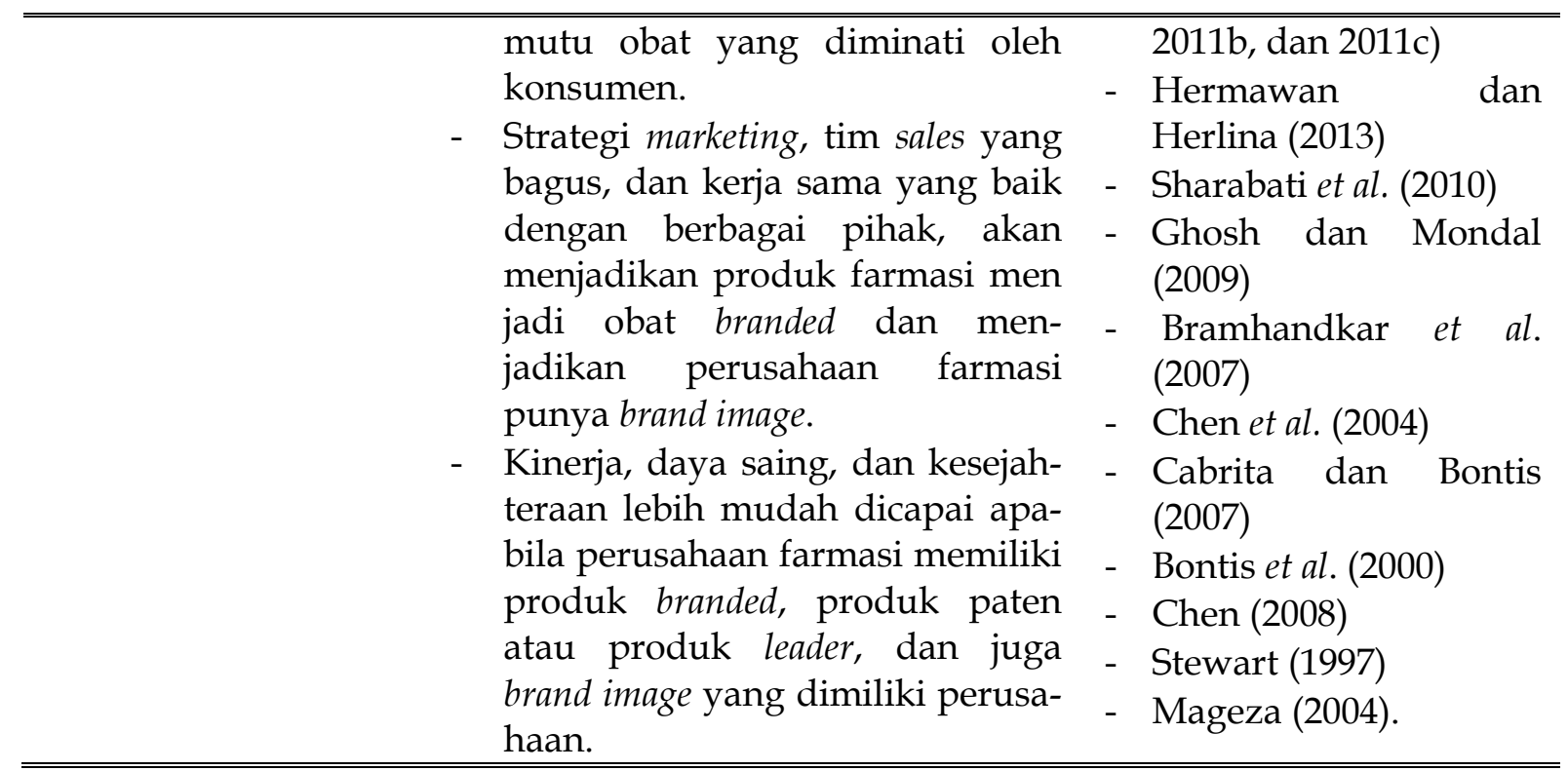

Sumber: Data Display dan Data Reduction

Penelitian ini berhasil menemukan peran-peran yang dimainkan oleh IC untuk aktivitas operasional, inovasi, peningkatkan kinerja, daya saing, dan kesejahteraan. Penelitian ini sebagai penelitian kualitatif juga dapat menjelaskan secara mendalam dan operasional tentang hasil-hasil penelitian kuantitatif yang menyatakan bahwa IC berpengaruh pada kinerja superior, competitive advantage, dan kesejahteraan. Penelitian ini juga dapat memberi kemanfaatan di bidang akuntansi manajemen karena berhasil mengeksplorasi aktivitas-aktivitas non financial dalam bentuk IC, aliran knowlegde, dan memberdayakannya menjadi intellectual property (brand product dan brand image) yang berkontribusi pada kinerja, daya saing, dan kesejahteraan. Karena keterkaitan IC dengan praktik akuntansi manajemen terletak pada penganggaran biaya, aktivitas non financial, dan memberikan informasi yang bermanfaat bagi perusahaan untuk mengidentifikasi, mengukur, mengomunikasikan pemicu nilai yang diharapkan bagi pengembangan sistem informasi pengukuran kinerja dan alokasi sumber daya (Hermawan, 2011c).

Kemanfaatan lain dari hasil penelitian ini untuk akuntansi manajemen adalah keterkaitan antara pengelolaan $H C$ dalam bentuk human resource management (HRM) dengan kinerja organisasi dan competitive advantage. Sebagaimana dinyatakan oleh Kouhy et al. (2009) bahwa kebijakan "job for life" lebih memandang human resource sebagai assets daripada costs. Hal ini sama seperti hasil penelitian ini yang menyatakan bahwa $H C$ memegang peran paling penting dalam pengelolaan $I C$ dan $H C$ dipandang sebagai assets bagi perusahaan farmasi di Indonesia. Outcome dari aktivitas HRM juga dapat dilaporkan ke dalam laporan akuntan manajemen perusahaan. Demikian pula untuk mencapai competitive advantage melalui strategic HRM lebih menekankan pada pendekatan strategis melalui pengelolaan HC yang dimiliki perusahaan.

Kontribusi berikutnya hasil penelitian ini terkait dengan masih sangat sedikitnya penelitian IC non keuangan seperti ini yang lebih banyak menggali aset-aset tersembunyi dan mengembangkan strategi untuk mencapai tujuan perusahaan sebagaimana rekomendasi Kannan dan Aulbur (2004). Penelitian IC non keuangan seperti ini juga memberikan kontribusi pada keberagaman penelitian IC yang selama ini lebih banyak dilakukan pada IC aspek keuangan. Memang perkembangan penelitian IC di Indonesia masih sangat didominasi oleh peneliti- 
an IC keuangan. Menurut banyak referensi dan hasil-hasil penelitian bahwa penelitian IC dapat dikelompokkan menjadi dua, yakni penelitian IC keuangan dan penelitian IC non keuangan. Penelitian IC keuangan akan terkait dengan analisis laporan keuangan guna menilai kinerja keuangan perusahaan. Penelitian IC keuangan ini membutuhkan pemahaman dan berkontribusi pada pengembangan akuntansi keuangan dan manajemen keuangan. Sementara itu, untuk penelitian IC non keuangan akan terkait dengan pengelolaan, evaluasi dan optimalisasi aset-aset tersembunyi, serta menyusun strategi untuk dapat meningkatkan kinerja non keuangan perusahaan yang akhirnya akan meningkatkan kinerja keuangan perusahaan. Penelitian IC non keuangan akan terkait dengan akuntansi manajemen dan juga strategic management accounting. Gambar 1 menjelaskan tentang penelitian IC keuangan dan IC non keuangan.

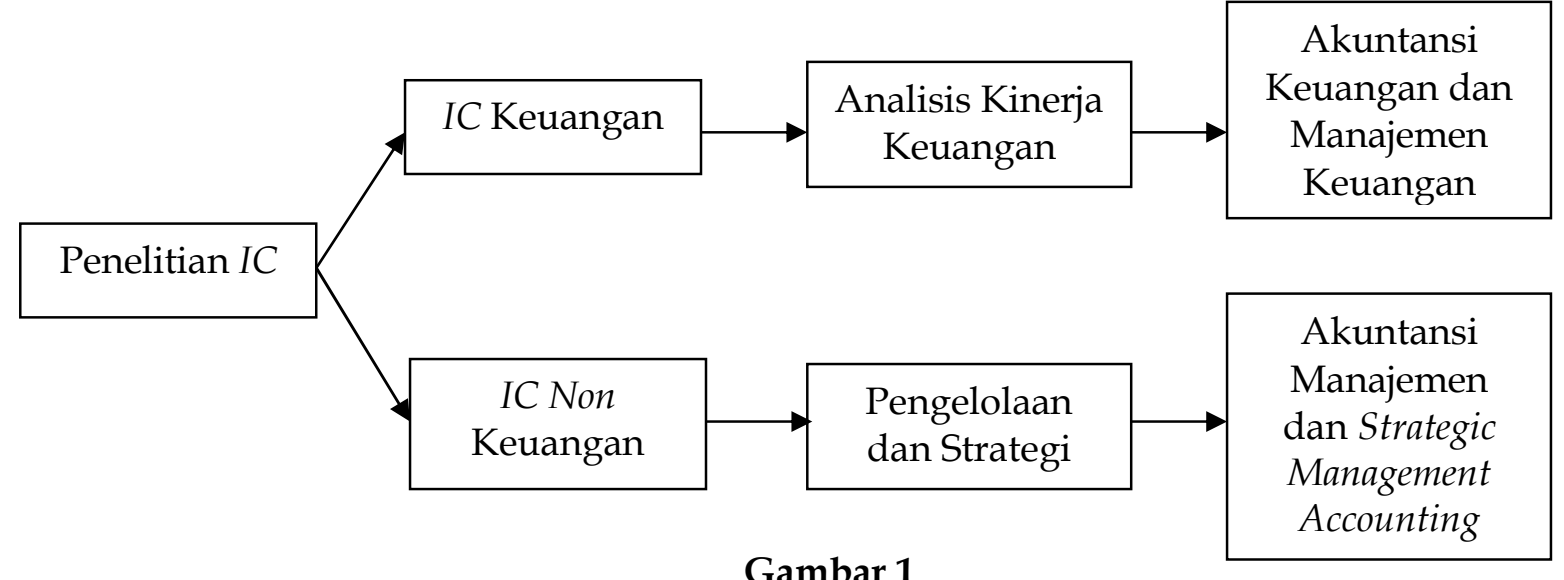

Sumber: Dirangkum dari Berbagai Referensi

Kontribusi selanjutnya dari hasil penelitian ini adalah pada aspek metode penelitian yang dilakukan. Jenis penelitian ini adalah kualitatif interpretive. Sebagaimana Nelson (2007), Kong dan Ramia (2010) bahwa penelitian IC non keuangan yang menggali aset-aset tersembunyi, tacit knowledge, dimensi yang non verbal membutuhkan wawancara mendalam dan juga interpretasi makna dari para key informant. Lebih lanjut bahwa penelitian kualitatif interpretive seperti ini dapat juga dikategorikan ke dalam interpretive accounting research (IAR) (Lehman, 2011) atau Lukkaa dan Modell (2010) menyebutnya sebagai interpretive research (IR) in management accounting. Memang terkait dengan intellectual capital atau juga aliran pengetahuan ini masuk ranah management accounting research kelompok intellectual reseource management (Harris dan Durden, 2011). Penulis yakin bahwa riset kualitatif interpretive untuk bidang akun- tansi manajemen akan berkembang seiring kebutuhan perusahaan dan organisasi untuk melakukan pengelolaan IC dengan cara identifikasi komponen kunci atau indikator $H C, S C$, dan $R C$.

\section{SIMPULAN DAN SARAN}

Simpulan penelitian ini adalah makna peran intellectual capital dalam persepektif the role theory terkait dengan aktor atau pihak yang memainkan peran pengelolaan intellectual capital, yakni manajer human resource development untuk human capital, manajer operasional dan manajer produksi untuk structural capital, dan manajer penjualan pemasaran untuk relational capital. Pihak yang paling berperan untuk pengelolaan intellectual capital adalah manajer human resource development untuk human capital. Peran Intellectual Capital tersebut dapat dimainkan per komponen secara mandiri (human capital, structural capital, 
atau relational capital) untuk tiap aktivitasnya dan dapat juga ketika diintegrasikan menjadi satu kesatuan intellectual capital. Sementara itu, makna peran intellectual capital perspektif the resource based theory terkait dengan intellectual capital berperan bagi keseluruhan kegiatan operasional perusahaan farmasi, meningkatkan daya inovasi, kinerja, daya saing, dan kesejahteraan.

Saran penelitian ini adalah perusahaan farmasi harus dapat meningkatkan peran intellectual capital karena telah terbukti mampu meningkatkan kegiatan secara operasional, meningkatkan daya inovasi, kinerja, dan kesejahteraan perusahaan. Peran pengelolaan intellectual capital tersebut ada pada manajer human resource development untuk pengelolaan human capital, manajer operasional atau produksi untuk pengelolaan structural capital dan manajer pemasaran atau penjualan untuk pengelolaan relational capital. Peningkatan peran intellectual capital tersebut harus dilakukan oleh perusahaan farmasi baik secara individu manajer human resource development, manajer operasional, manajer pemasaran dan juga harus diintegrasikan diantara ketiga manajer tersebut sehingga terjadi sinergitas yang akhirnya membentuk nilai bagi intellectual capital di perusahaan farmasi.

Keterbatasan penelitian ini adalah tidak bisa dilakukannya observasi langsung berperan serta aktif di perusahaan farmasi sehingga in depth interview dilakukan di luar kantor dan di luar jam kerja para informan manajer perusahaan farmasi. Namun hal tersebut dapat dipahami oleh peneliti karena kesibukan para informan dan pastinya akan menganggu aktivitas kerja di perusahaan farmasi. Atas dasar alasan tersebut juga bahwa penelitian ini adalah studi interpretive. Saran untuk peneliti berikutnya adalah mempertimbangkan perusahaan atau obyek penelitian yang dapat memberikan rekomendasi pada peneliti untuk melakukan observasi langsung ke perusahaan.

\section{DAFTAR PUSTAKA}

Badan Pengawas Obat dan Makanan (BPOM) Republik Indonesia. 2006. Pedoman Cara Pembuatan Obat Yang Baik. Badan POM. Jakarta.

Barney, J. 1991. Firm Resources and Sustained Competitive Advantage. Journal of Management 17(1): 99-120.

Belkaoui, A. R. 2003. Intellectual Capital and Firm Performance US Firm. A Study of The Resource Based and Stakeholders View. Journal of Intellectual Capital 4(2): 215-226.

Boekestein, B. 2006. The Relation between Intellectual Capital and Intangible Assets of Pharmaceutical Companies. Journal of Intellectual Capital 7(2): 241253.

Bontis, N. 2001. Assessing Knowledge Assets: A Review of the Model Used to Measure Intellectual Capital. International Journal of Management Reviews 3(1): 41-60.

--_--. 1999. Managing an Organizational Learning System by Aligning Stocks and Flows of Knowledge: An Empirical Examination of Intellectual Capital, Knowledge Management, and Business Performance. Dissertation. The University of Western Ontario. Canada.

---_--_--. 1996. There's A Price on Your Head: Managing Intellectual Capital Strategically. Ivey Business Journal formerly Business Quarterly 60: 40-47.

Bontis, N., dan J. Fitz-Enz. 2002. Intellectual Capital ROI: A Casual Map of Human Capital Antecedents and Consequents. Journal of Intellectual Capital 3(3): 223247.

Bontis, N., W. C. C. Keow, dan S. Richardson. 2000. Intellectual Capital and Business Performance in Malaysian Industries. Journal of Intellectual Capital 1(1): 85-100.

Bramhandkar, A., S. Erickson, dan I. Applebee. 2007. Intellectual Capital and Organizational Performance: An Empirical Study of the Pharmaceutical 
Industry. The Electronic Journal of Knowledge Management 5(4): 357-362.

Brooking, A. 1997. Intellectual Capital. International Thompson Business Press. London.

Cabrita, M. d. R., dan N. Bontis. 2008. Intellectual Capital and Business Performance in the Portuguese Banking Industry. International Journal Technology Management 43(1-3): 212-237.

Cabrita, M. d. R., J. L. de Vas, dan N. Bontis. 2007. Modelling The Creation of Value From Intellectual Capital: A Portuguese Banking Perspective. International Journal Knowledge and Learning 3(2-3): 266-280.

Caddy, I. 2000. Intellectual Capital: Recognizing Both Assets and Liabilities. Journal of Intellectual Capital 1(2): 129146.

Chartered Institute of Management Accountants (CIMA). 2005. Knowledge Management and Its Impact on The Management Accountant. Research Report 8.

Chen, Y. S. 2008. The Positif Effect of Green Intellectual Capital on Competitive Advantage of Firms. Journal of Business Ethics 77(3): 271-286.

Chen, J., Z. Zhu, dan H. Y. Xie. 2004. Measuring Intellectual Capital: A New Model and Empirical Study. Journal of Intellectual Capital 5(1): 195-212.

Cohen, S., dan N. Kaimenakis. 2007. Intellectual Capital and Corporate Performance in Knowledge-Intensive SMEs. The Learning Organizations 14(3): 241-262.

Choo, C. W., dan N. Bontis. 2002. Knowledge, Intellectual Capital, and Strategy: Themes and Tensions. Edisi Internasional. The Strategy Management of the Intellectual and Organizational Knowledge. Oxford University Press. New York.

Creswell, J. W., W. E. Hanson., V. L. P. Clark, dan A. Morales. 2007. Qualitative Research Designs: Selection and Implementation. The Counseling Psychologist 35(2): $236-264$.
Daum, J. H. 2005. Intengible Assets Based Enterprise Management: A Practical Approach. Proceedings of 2005 PMA IC Symposium, Stern School of Business. New York University Manhattan.

Edvinsson, L., dan M. Malone. 1997. Intellectual Capital: Realizing Your Company's True Value by Finding Its Hidden Brainpower. Harper Collins Publishers Inc. NewYork.

Elder, G. H, Jr. 1975. Age Differentiation and Life Course. Annual Review of Sociology.

Ghosh, S., dan A. Mondal. 2009. Indian Software and Pharmaceutical Sector IC and Financial Performance. Journal of Intellectual Capital 10(3): 369-388.

Harris, J., dan C. Durden. 2011. Directions in Management Accounting Research: An Analysis of Contemporary Issues and Themes. Asia Pasific Conference Paper 121.

Harrison, S. and P. H. Sullivan. 2000. Profiting From Intellectual Capital: Learning From Leading Companies. Industrial and Commercial Training 32(4): 139-148.

Hermawan, S. 2010. Pengukuran Non Keuangan Mengungguli Pengukuran Keuangan Pada Intellectual Capital. Jurnal Akuntansi Manajemen Bisnis dan Sektor Publik (JAMBSP) STIESIA Surabaya 7(1): 118-141.

2011a. The Integration of Intellectual Capital and Knowledge Management to Improve the Business Performance and Achieve the Competitive Advantage. Proceeding International Seminar 22 August. Faculty of Economic and Business. Hasanuddin University. Makassar Indonesia. 2011b. Optimalisasi Intellectual Capital Guna Meningkatkan Kinerja Bisnis IKM Batik dan Memenangkan Persaingan di CAFTA. Proceeding Seminar Nasional 1 Oktober. Fakultas Ekonomi dan Bisnis. Universitas Muhammadiyah Malang. 
2011c. Praktik Akuntansi Manajemen dan Kinerja Bisnis; Tinjauan Persepektif Intellectual Capital. Jurnal OPTIMAL FE Universitas Islam "45" Bekasi 5(2): 179-193.

Hermawan, S., W. Hariyanto., H. Ernandi., S. Iswati, dan Z. Fanani. 2012. Model Pengelolaan dan Pengembangan Intellectual Capital Guna Meningkatkan Kinerja Bisnis Industri Farmasi dan Meraih Keunggulan Bersaing Tingkat Global. Laporan Penelitian Hibah Pekerti DP2M DIKTI Kemendikbud.

Hermawan, S., dan S. Herlina. 2013. Studi Interpretif Identifikasi dan Interaksi Intellectual Capital Terhadap Kinerja Perusahaan. Jurnal Reviu Akuntansi dan Keuangan FEB Akuntansi Universitas Muhammadiyah Malang 3(1): 335-347.

$\mathrm{Hsu}, \mathrm{H}$. Y. 2006. Knowledge Management and Intellectual Capital. Dissertation. Southern Illinois University. Carbondale USA.

Hussien, A. 2009. The Use of Triangulation in Social Science Research: Can Qualitative and Quantitative Methods are Combined? Journal of Comparative Social Work 1(1): 1-2.

Ikatan Sarjana Farmasi Indonesia (ISFI). 2009. Kode Etik Apoteker Indonesia. Konggres Nasional Ke XVII. Jakarta.

International Federation of Accountants (IFAC). 1998. The Measurement and Management Of Intellectual Capital: An Introduction. New York. USA.

Kamath, G. B. 2008. Intellectual Capital and Corporate Performance in Indian Pharmaceutical Industry. Journal of Intellectual Capital 9(6): 684-704.

Kannan, G, dan W. G. Aulbur. 2004. Intellectual Capital Measurement Effectiveness. Journal of Intellectual Capital 5(3): 389-413.

Khalique, M., J. A. N. Shaari., A. B. M. Isa, dan A. Ageel. 2011. Role of Intellectual Capital on the Organizational Performance of Electrical SMEs in Pakistan. International Journal of Business and Management 6(9): 253-257.
Kong, E., dan G. Ramia. 2010. A Qualitative Analysis of Intellectual Capital in Social Service Non Profit Organizations: A Theory-Practice Divide. Journal of Management and Organization 16(5): 656676.

Kouhy, R., R. Vedd., T. Yoshikawa, dan J. Innes. 2009. Human Resource Policy, Management Accounting, and Organisational Performance. Journal Human Resource Costing \& Accounting 13(3): 245-263.

Lehman, G. 2011. The Management of Sustainability: The Art of Interpretation. JAMAR 9(1): 75-88.

Linton, R. 1936. Study of Man. Norwalk CT Appleton-Century-Crofts. USA.

Lukkaa, K., dan S. Modell, 2010. Validation in Interpretive Management Accounting Research. Accounting, Organizations and Society 35(4): 462-477.

Mageza, P. Z. 2004. Intellectual Capital As A Creator of Wealth and Shareholder Value For An Organization. Short Dissertation. Rand Afrikaans University. USA.

Marr, B. 2008. Make The Invisible Visible: Identify Intellectual Capital. http://www. cimaglobal.com. Diakses 23 Maret 2010.

Marr, B., dan G. Schiuma. 2001. Measuring and and Managing Intellectual Capital and Knowledge Assets in New Economy Organizations. Handbook of Performance Measurement. Edisi Internasional. Gee. London.

Marshall, M. N. 1996. Sampling for Qualitative Research. Family Practice an International Journal 13(6).

Marshall. 2006. Data Collection Method. http://www.sagepub.com/upm-data/10985_ Chapter_4.pdf. Diakses 20 Desember 2010.

Miles, M. B., dan A. M. Huberman. 1984. Qualitative Data Analysis. Sage Publication Inc. USA.

Moon, Y. J, dan H. G. Kym. 2006. A Model for the Value of Intellectual Capital. Canadian Journal of Administrative Sciences 23(3): 253-269. 
Nelson, D. K. 2007. A Framework for Developing Knowledge Maps for a Not-for-Profit Firm: A Case Study. Dissertation. Robert Morris University. USA.

Rahardjo, M. 2010. Triangulasi dalam Penelitian Kualitatif. www.mudjiarahadjo.com. Diakses 29 Juli 2012.

Roos, J., G. Roos, N. Dragonetti, dan L. Edvinsson. 1997. Intellectual Capital: Navigating the New Business Landscape. MacMillan Press. London.

Sampoerno, 2007. Kapabilitas Teknologi dan Penguatan R \& D: Tantangan Industri Farmasi Indonesia. Majalah Farmasi Indonesia 18(4): 199-209.

Senton, A. K. 2004. Strategies for Ensuring Trustworthiness in Qualitative Research Project. Education for Information 22(2): 63-75.

Sharabati, A. A. A., S. N. Jawad, dan N. Bontis. 2010. Intellectual Capital and Business Performance in the Pharmaceutical Sector of Jordan. Management Decision 48(1):105-131.
Shih, K. H., C. J. Chang, dan B. Lin. 2010. Assessing Knowledge Creation and Intellectual Capital in Banking Industry. Journal of Intellectual Capital 11(1): 74-89.

Sofian, S., M. Tayles, dan R. Pike. 2005. A Study On The Intellectual Capital and Management Accounting Practices: A Combination of Qualitative and Quantitative Approaches. $3^{\text {rd }}$ International Qualitative Research Convention 21-23 August Senai Johor Malaysia.

Stewart, T. A. 1997. Intellectual Capital-The New Wealth of Organization. Nicholas Brealey. London.

Strauss, A., dan J. Corbin. 2003. Dasar-Dasar Penelitian Kualitatif. Penerbit Pustaka Pelajar. Yogyakarta.

Sveiby, K. E. 2010. Method for Measuring Intangibles Assets.

www.sveiby.com/articles. Diakses 10 Desember 2010. . 1997. The intangible Assets Monitor. Journal of Human Resource Costing and Accounting 2(1): 73-97.

Wernerfelt, B. 1984. A Resource Based View of the Firm. Strategic Management Journal 5(2): 171-180. 